\title{
A Literature Review: Digital Marketing Trends in Indonesia During the COVID-19 Pandemic
}

\author{
Nabila Astari \\ Universitas Indonesia \\ Email: nabila.astari01@ui.ac.id \\ *corresponding author
}

\author{
Keywords: \\ COVID-19 \\ Digital Marketing \\ Trends \\ Pandemic \\ Literature Review
}

\begin{abstract}
This study is about the current trend and upcoming future trends in digital marketing. They use secondary data, a literature review based on current literature, and studies about what is currently happening in the business world. Other sources are used in this study, such as articles, research, reports, news, website, and many more. During this digitization era, especially during the COVID-19 pandemic, consumers look for information and try to find the best option using the internet. It made some shifts in the market from conventional marketing to digital marketing. Now brands are using SEO, SEM, influencer marketing, and other digital marketing approaches. In this study, we acknowledge that brands receive benefits from digital marketing. All brands that prove this are racing to connect with consumers using social media and digital channels to increase consumer knowledge about the brand and create brand loyalty. This study will focus on digital marketing approaches that this study suggests for companies during the pandemic.
\end{abstract}

This is an open access article under the CC-BY-SA license.

\section{INTRODUCTION}

As of the writing process, currently there is a virus called Novel Coronavirus that is still mutating and infecting the world. Novel Coronavirus or better known as COVID19 is a new virus with a strange mutation that still does not have a cure or medicine to it. The disease is currently changing the lives of people around the globe. The As of the writing process, currently, there is a virus called Novel Coronavirus that is still mutating and infecting the world. Novel Coronavirus, better known as Covid-19, is a new virus with a strange mutation that still does not cure or medicine. The disease is currently changing the lives of people around the globe. The COVID19 pandemic created a considerable impact that also led to creating a health crisis everywhere. The Centers for Disease Control and Prevention, usually called CDC USA, says COVID19 is a contagious virus that can cause death. In America, the number of people infected by COVID-19 virus infection and is heavily infected is threatened by death, and the number is increasing rapidly. Several measures are taken to slow down the infection rate and control the pandemic situation globally and nationally (Fernandez \& Shaw, 2020).

The Covid-19 pandemic is impacting daily activities and has created a considerable heavy economic impact in almost every country. In the business world, social distancing conditions have forced companies to set up remote working arrangements and ask the workers to do it remotely from their own houses (Choudhury \& Li, 2020). Many employees can quickly catch up and keep up with changes by implementing digital transformation in their work, online interaction using video conferencing platforms such as Zoom. It reports a 78\% revenue spike, same as its competitor Google Meet also reports a significant number of increase up to $60 \%$ users, and in reports are also stated that 2 billion minutes are spent on online meetings daily (Kim, 2020). It is predicted that if the pandemic ends, many employees are no longer willing to work physically and return to the office back to normal because they are comfortable and accustomed to working remotely.

The covid-19 pandemic created a considerable impact that also led to creating a health crisis everywhere. The Centers for Disease Control and Prevention, usually called CDC USA, says Covid-19 is a contagious virus that can cause death. In America, the number of people infected by Covid-19 virus infection and is heavily infected is threatened by 
death, and the number is increasing rapidly. Several measures are taken to slow down the infection rate and control the pandemic situation globally and nationally (Fernandez \& Shaw, 2020).

The Covid-19 pandemic is impacting daily activities and has created a considerable heavy economic impact in almost every country. In the business world, social distancing conditions have forced companies to set up remote working arrangements and ask the workers to do it remotely from their own houses (Choudhury \& Li, 2020). Many employees can quickly catch up and keep up with changes by implementing digital transformation in their work, online interaction using video conferencing platforms such as Zoom. It reports a 78\% revenue spike, same as its competitor Google Meet also reports a significant number of increase up to $60 \%$ users, and in reports are also stated that 2 billion minutes are spent on online meetings daily (Kim, 2020). It is predicted that if the pandemic ends, many employees are no longer willing to work physically and return to the office back to normal because they are comfortable and accustomed to working remotely.

Companies are experimenting with new ways of working to cope with the current situation, centered on using software and the internet as primary media. This is expected to create a digital working culture as influential as working at the office before the pandemic hits. While businesses are making transformation and transition as effective and quick as possible, some other essential consequences need to be considered to ensure their continuity in the market: understanding the consumer and market behavior that changes because of the Covid-19 pandemic. Most recent studies and research done by management practitioners and academic conducted studies focus on digital transformation from a business perspective (Kim, 2020). According to the "Mere Urgency Effect," people tend to allocate most of their primary resources to solve urgent problems most of the time (Zhu \& Hsee, 2018).

Marketing is also affected by the Covid-19 pandemic. Companies that previously promoted conventionally had to change their marketing method to digital restrictions on movement to maintain social distance. Digital marketing is a solution to overcome the situation of restricting movement and maintaining social distance. Consumers' irrational decision-making often happens during a pandemic situation like now, like what recently happened at the beginning of the pandemic outbreak is stockpiling essential household items until unpredicted items like toilet paper, and this behavior happens around the world. There are many arguments around this change of consumers' behavior that leads to panic buying and hoarding. It seems to be a rational consumer behavior at uncertain times like this pandemic (Lufkin, 2020). Not only does it give a lesson to brands and businesses, but the current pandemic is also teaching consumers lessons to carefully make their choices because all decisions are interconnected and impact a product or brand preference. Consumers are more likely to judge their personal preference based on an essential evaluation of their self-concept or consumer identity based on their responsible consumption and prosocial product or brand choice (He, Li, \& Harris, 2012). It can be concluded that the company must adapt to the needs of consumers and the circumstances using a new marketing approach and following the pandemic situation. This study discusses several perspectives on digital marketing for the future and current trends.

\section{METHOD}

This study approach uses a conceptual base that reflects digital marketing trends and prospects for now and in the future. A descriptive technique used for the data analysis is a critical approach to analyzing literature about digital marketing and relating it to the research result.

\section{A. Conceptual Study}

Several research, studies, papers, and articles are presented below to provide a detailed insight into internet marketing or digital marketing. Below are the findings from the literature used:

Digital marketing is now described simply as 'achieving marketing objectives through digital technology (Chaffey, 2013). Digital marketing applies renewable technology to marketing that aims to increase consumer knowledge and interaction by following their needs (Chaffey, 2013). Developed countries and global companies had already implemented digital marketing before the pandemic because they realized the importance and benefits. For a business to be successful, there must be a combination of online methods with traditional or conventional methods to meet the needs of targeted customers (Parsons, Zeisser \& Waitman, 1996). According to Kiani (1998), new business opportunities are created due to the introduction of new technologies for companies or brands to manage websites to achieve business goals more efficiently. Online advertising is an impactful marketing tool to build a brand image, increase traffic to the advertisements, and achieve success according to targets sets (Song, 2001). To measure the ROI achieved from digital marketing is considered more trackable and cost-effective (Pepelnjak, 2008).

Marketing goals become more achievable because of the digital marketing phenomenon. It refers to a customizable and mass distribution approach. User-centric is becoming the new fundamental aspect that opens our way of thinking about digital marketing, and it creates a convergence of technology and reaches more devices. It becomes more scalable and interactive. Different approaches and strategies are created and open up too much potential. Digital marketing provides new opportunities for companies to gain revenue from multi-stakeholder engagements, including consumers, employees, 
and the potential public (Purkayastha \& Sharma, 2016). Incorporating digital marketing into a business plan can reduce the possibilities of failure and create opportunities for businesses to grow and gain profit. That is why business leaders are suggested to do those measures. There are several benefits of implementing digital or online marketing like; economic aspects, multi-targeting different demographics, convenient product and service for consumers, and speeding up purchase decisions (Durmaz \& Efendioglu, 2016).

The creation of digital content that includes accessibility, navigation, and speed is defined as the primary marketing characteristics to create digital marketing that produces results for businesses (Kanttila, 2004). Another tried and tested tool for achieving success through digital marketing is word of mouth (WOM) on social media and making the site popular (Trusov, Randolph, \& Koen, 2009). Moreover, WOM is associated with recruiting new members and increasing traffic on the website, increasing visibility in terms of marketing.

For example, Facebook has become a starting gate for businesses to reach out and communicate their products to millions of people thanks to their service and product. It creates opportunities and opens up multi approaches for digital marketing in the platform and also the marketplace. This new opportunity is possible if the lead or the manager is aware of the benefits of using communication strategies to improve the consumer engagement experience (Mangold, \& Faulds, 2009). An effective performance is achievable if the campaign is conducted effectively and measured with a performance measurement indicator to give a better view to the marketing professionals on the digital marketing impacts. The change of market dynamics also changes the respect to a young audience as they are the primary social media users. Adoption and integration to the marketing communication plan overall need to be done and are essential (Rohm, 2011). Reviews from consumers written online also become crucial for a business's overall marketing strategy (Rohm, et. al, 2013). Effective communication methods like online approaches are considered more effective than traditional approach methods (Helm, et. al, 2013). A previous study proved that adaption to social media creates good self-esteem and is a sign of motivation for businesses and marketing professionals to ensure it is incorporated well in their plans and strategies (Arnott, 2013). Consumer experience on the web affects the process of consumers making decisions and increasing their purchases online (Cetină, 2012).

\section{RESULTS AND DISCUSSION \\ A. Digital Marketing Prospect}

Indonesia is included in the top ten countries with the most significant internet users in the world. As the fifth country with 143.26 million internet users as of March 2019. The numbers are pretty different from Brazil, with 149.06 million users, which creates a 5.8 million internet user gap. Indonesia is not in the first rank. The first country is China with 829 million users, followed by India with 560 million users, and the third is America with 292.89 million internet users. Based on the data from Statista globally, there are 3.49 billion internet users. The rapid growth of internet users is also shown in the Statista data. In Indonesia, reportedly in 2018, the number of users is 95.2 million, and it grew $13.3 \%$ compared to the previous year, which is 84 million users. It is predicted that the number of users will continually grow by the coming years, with an average number of $10.2 \%$ until 2023. By 2023 it is predicted that Indonesia will reach 150 million internet users or people connected to the internet. (https://databoks.katadata.co.id/)

Data has shown, Indonesia's online trade transaction is proliferating. In 2014, the number of transactions at e-commerce reached IDR 25.1 trillion and kept growing in 2018. The number reached IDR 1441.1 trillion. Indonesia is one of the leading countries as the fastest growing e-commerce globally with $78 \%$ growth in 2018, based on British Research Institute - Merchant Machine. More than 100 million internet users in Indonesia are the main driver of e-commerce growth. It is reported that, on average, Indonesians spend USD 228 per person or convert around IDR 3.19 million per person on e-commerce shopping sites. (https://databoks.katadata.co.id/)

Excellent prospects are predicted to be contributed by digital marketing, so adjustments need to be made by a business to their market orientation strategy. According to Techopedia, digital marketing is a collection of sophisticated methods and tools to market products and services online over the internet. According to Dolan, Conduit, Fahy, \& Goodman (Dolan, et. al, 2017), online marketing enhances content and changes how individuals and organizations interact. A process of promoting a brand, product, or service using the internet as the medium is more known as internet or digital marketing (Tan, et. al, 2013). Potential benefits for a business like potential growth, cost reduction, elegant communication approach, controllable campaigns, consumer service improvement, and competitive landscape advantages can be received through the internet or digital marketing implementation. What needs to be done is to ensure the process is synced with the advantages taken from technology. Nevertheless, a natural new approach also comes with potential failure if it is not implemented in the right way. The failures can lead to lost productivity, income, and communication (Cheng \& Liu 2017).

\section{B. Internet Marketing}

Internet connects various souls without knowing regional boundaries. This network consists of millions of networks from various institutions, such as private institutions, public institutions, academic institutions, business institutions, 
government institutions, and many more. "The Internet is a combination of various technologies that creates a source of information this becomes the greatest humankind ever invented. The Internet also lays the groundwork for more channels of information than anyone created until the 20th century" (Phillips, 2013). Marketing is a broad term, one of the most well-known definitions says that "Marketing is a social process described as an effort for individuals and groups to obtain what they need and target through the creation of information about products to exchange value with other people" (Kotler, 2007). By linking these two fields, "Marketing principles can be applied directly on the Internet. What can be done on the Internet mainly involves creating web pages, internet advertising, and conducting marketing research, electronic commerce, and many more. Since internet marketing is new, it needs to be done with a different approach than traditional marketing" (Blažková, 2006). Internet marketing in daily life is often called in different terms like digital marketing, online marketing, web marketing, or even electronic marketing.

Internet marketing uses the website as the platform. However, it also includes using its website as an online promotion tool, like banner ads, search engines marketing, search engines optimization, PPC advertising, email subscription, and direct links or services from other websites drive traffic. Internet marketing is more than just a website with its contents. It is a complex process that links to many things. The interconnection between web portals, search engines, partner sites, blogs, B2B partners, customers, outsourcing partners, and more is also included in Internet marketing. It comes down to extensive use and term.

\section{Internet Marketing Trends and Techniques}

Creating an internet marketing plan also defines specific goals and metrics, and to achieve the goals, a proper strategy is needed. Companies can use internet marketing to gain advantages for their business and also counter possible threats. Electronic marketing focus on the way of approach companies use to introduce their brand using digital device and internet platforms to reach their pre-determined marketing goals that have been set. In this study, we focus on marketing from content and social media to marketing technology, analytics. This is done to find and conclude the summary for marketing trends at the current pandemic situation. Below is the summary created from different marketing trend articles that different authors write and experts. All materials are read, dissected, analyzed, and summarized as below:

\section{Search Engine Optimization (SEO)}

Search Engine Optimization, more known as its acronym SEO, is defined as a mechanism. This mechanism allows people to search the internet using a defined portal to get the most relevant result based on the online search keyed in. SEO helps brands appear on the right keywords at the right place and the appointed time from the marketer side. SEO becomes a competition, and marketers can improve their appearance on the search page result by improving their website quality score, back-end reparation to meet the current search engine competition, and top the list (Sen, 2005). Search engines are classified into three kinds:

- Crawler-based search engines: This search engine uses a crawler or spider program to create a database from the world wide web, using a web robot method. These robots work as the program to crawl on the host system and recover data from destinations on the world wide web using standard conventions. In a simple explanation, it is a natural crawling process that searches every part of the world wide web, connects digital records, and collects the data indicated by HTM structure (Thelwall, 2015).

- Human-powered directories: Often referred to as "open index systems," this process relies on a human to drill and post the findings. The site owner displays a brief overview of the site to the registry and the recorded categories. The submitted site is then physically inspected and included in the appropriate class or not included for submission. The keywords entered in the search box will be coordinated with the local system. Decent sites with good content may be judged not compared to sites with poor content (Burghardt, et. al, 2012).

- Hybrid search tools: This uses manual and crawler-based sorting to post search results locally. Like the most known site Google, most crawl-based web indexes use the crawler as an essential component and use manual filtering as an additional instrument. For example, when a website is categorized as spam, before concluding the status, a manual survey must be done to validate the result (Ahlers, 2012).

Many experts say that SEO is no longer the focus and is dead, and trying to use it as a marketing tool is futile. However, the reality is that Google continues to innovate and prevent algorithms from fabricating and filtering sites or websites that match at the top of SERP searches (Search Engine Result Pages). So, investing in SEO can be a decision that companies must make so that consumers can find the company in their search. The company's website should discuss content that matches the targeted word matching in search, content dissemination, indexing, and interpretation are carried out so that the content appears on search pages and becomes the top of search results. This marketing strategy is one of the least expensive and will bring organically generated traffic to the business through the targeted website. However, this marketing process requires effort, effort, and persistence in maintaining an SEO presence. 


\section{Search Engine Marketing (SEM)}

Different from SEO, Search Engine Marketing, more known as SEM, is a paid placement on a search engine, contextual advertising on specific keywords responding to users' search on the search engines. Paid placement is done by bidding for a particular search keyword. The final placement will depend on other bidders that bid for the same keyword and the number of leads (PPC) the website receives from sponsored links (Colborn, 2005). SEM is a comprehensive strategy to bring traffic from search engines to targeted websites, done using paid efforts. SEM is also known as Paid Search Marketing. SEM has various models that vary and tend to be complex. Their use can be determined based on the type needed and the marketing, such as PPC (pay-per-click) or CPC (cost-per-click), or CPM (cost-per-thousand impressions). The types of platforms for SEM are many and varied. Google Ad Words (on the Google Network) is still the best-selling and favorite platform, followed by Bing Ads (Yahoo Bing Network). Display Advertising, Search Retargeting \& Site Remarketing, Mobile Marketing, and Paid Social Advertising is SEM products.

\section{Content Creation}

In traditional marketing, audiences are passive, whereas the approach is different in internet marketing, integrated with marketing communication tools. Here the audience is more active or could be seen as interactive with the help of tools like social media; it helps marketers engage with their audience and encourage them to be active parties in content creation (Wade, 2009). Based on previous studies (Smith, et. al, 2012) (Lee, 2013) (Galea, 2007) (Ryan \& Jones, 2009), brands or companies often experience a loss of control when they create marketing campaigns through social media; this happens because the audiences actively participate in the content creation process. User-generated content or often called UGC is content created or produced directly by the audience (Farrar, 2010). A single online content contribution - blog or forum or others - can leave a long-lasting effect on their company reputation. That is why control over content creation on the internet becomes a critical issue for marketers (Ryan \& Jones, 2009).

With content creators owned by companies, they must be creative in content creation, not only topics that need to attract attention, but also skills in linking and linking content created indirectly to companies or brands and products that are the primary target. In addition, content adjustments need to be made for various platforms. For example, content on mobile marketing must be adapted to the size of the screen so that the content created must be clear, concise, and concise. An effective content creation strategy will attract more consumers and create more interest in the more information presented. With the pandemic, the rate at which people use mobile phones and digital devices has increased, so has the time to use the internet. Content creation is a golden opportunity for a marketing approach and could be in various approaches. Digital storytelling is one of them. Digital storytelling is a new way to build and maintain the reputation it is concerning reputation to tell the things the company has done and build a brand story (Widianingsih \& Cahyani, 2020).

\section{Social Media Marketing}

Social media opens opportunities to interact directly by using a digital communication approach between consumers directly with companies or brands, according to Mangold and Faulds (2009). Companies or brands, and consumers can build communication to create and build strong brand loyalty outside of traditional methods (Jackson, 2021), which is recognized by promoting products and services and online communities of brand followers or referred to as loyal consumers (Kaplan \& Haenlein, 2010). According to eMarketer (2021), companies are increasingly adopting social media as a platform for carrying out various marketing activities such as branding, market research, customer relationship management, service provision, and sales promotion.

Social media marketing is a branch or further step of SEM. This process is carried out to direct consumers from social media (Facebook, Twitter, LinkedIn, and others). One voice with the discussion in the previous section above, content is critical. Without good content creation and relevant content results, there will be no process where consumers share and like posts made by companies. Marketing efforts on social media will have a significant impact in helping companies or brands do branding and sales. The use of various devices approaches, and strategies in communicating directly with consumers tends to change a lot with the rapid development of technology and with the emergence of social media; To follow and adapt to the changes that occur, businesses must adjust and learn how to use social media following the business plan to achieve the desired and expected goals (Mangold and Faulds, 2009). To create a successful marketing campaign through social media, consumers must be open to technology. With the current pandemic, consumer openness to technology is very advanced and proliferating. This is an excellent opportunity for the company to reach its consumers digitally.

\section{Digital Display Advertising}

Display advertising is an essential component for a company or brand, significantly increasing "brand awareness" among consumers (Damien Geradin \& Dimitrios, 2019). Digital display advertising is more like traditional offline advertising. Digital display advertising is visual-based advertising (e.g., text, images, or video). Examples of display ads 
are banners at the top of a newspaper's web page promoting a new car model or a video promoting a new film.

This type of advertising is part of SEM. Various display ad formats can be used as described above to target potential consumers; ads that can be text, images, banners, interactive multimedia, or videos. Companies or brands must adjust the message to be conveyed by referring to consumer characteristics, including interests, topics, content, or consumer positions in the consumer journey. Digital display advertising is relatively expensive compared to other advertisements. In its execution, experts are needed to optimize ROI (Return of Investment) in digital display advertising.

\section{Mobile Marketing}

Mobile marketing is a two-way or multi-way communication and promotion from a company or brand to consumers, using mobile media, devices, or technology. Mobile marketing is interactive marketing involving two-way or multi-way communication. The forms of mobile marketing vary, such as mobile advertising, promotions, customer support, and other relationship-building activities. The use of interactive marketing activities is becoming increasingly important following the change of business dynamics (Ancarani and Venkatesh, 2003) (Bolton and Shruti-Saxena, 2009) (Deighton and Leora, 2009). Mobile marketing is distinguished from other marketing strategies by personalized targeting according to context. In other words, companies can create a campaign personalized based on consumer demographics, interest. The content is designed and delivered highly relevant and personalized mobile targeting content through mobile channels (SMS, in-app, and push notifications).

With the growth of mobile users, that day by day increases, mobile marketing is one of the most effective marketing approaches. Dushinski (2009), in his book, defines mobile marketing as a revolutionary tool to connect companies with each of their clients through their mobile devices at the right time and with the right message according to the consumer's circumstances. By referring to statistical data that provides information on the increasing use of mobile devices, this becomes a good alternative for the marketing process.

\section{Viral Marketing}

The term "viral marketing" is a phenomenon where consumers without payment can directly share and disseminate information relevant to the marketing of a product, which is intentionally initiated by a company or brand to create triggers and take advantage of word-of-mouth (WOM) behavior (Van der Lans, et.al, 2010). Such stimuli, often in the form of emails, are usually unsolicited (De Bruyn and Gary, 2008) but are easily forwarded to multiple recipients. These traits parallel those of infectious diseases, so the name and many of the conceptual ideas underlying viral marketing build on findings from epidemiology (Watts, 2004) (Peretti, 2007).

Viral marketing is often viewed as more cost effective compared to other traditional mass media advertising; it happens because viral marketing hands over the dissemination of marketing messages to consumers instead of spreading the message with their own media. To generate a maximum result, companies or brand should consider the four main critical success factors of viral marketing: (1) content, in terms of message appeal, is made to be memorable (Berger and Katy, 2021) (Schwartz, 2011) (Gladwell, 2002) (Porter and Guy J, 2006); (2) social network structure (Bampo, et.al, 2008); (3) recipients behavior, character and their initiative to share messages (Arndt, 1967); and (4) seeding strategy, the strategy to determine initial target consumer groups selected as initiators of viral marketing campaigns (Bampo, et.al, 2008) (Kalish, et.al, 1995) (Libai, et.al, 2005). The last factor becomes very important, because it is entirely under the control of the marketer who can explore social characteristics (Toubia \& Stephen, 2009) or choosing the network metrics that can be observed in depth. As at the beginning of the pandemic, the brand Sasa managed to dominate the market with a very simple viral marketing approach, namely, mothers quarreled during a wedding which ended with a brand reveal process taking place. This is effective for increasing brand image during a pandemic when consumers have a lot of time to view news and share information on mobile devices.

\section{Influencer Marketing}

Influencer marketing in now a hot topic for research, the COVID19 has created an even greater impact on influencer marketing because young people's media consumption habits is changing. Before the pandemic, there was much debate about the effectiveness of influencers in the context of marketing or promotion. Based on previous research done by the Association of National Advertisers (ANA) in 2018, it says that from $75 \%$ of consumers who engage in influencer marketing, only $36 \%$ believe it is effective. Adding to that fact, a research by Stackla Firm found another fact on consumers, they say that they believe that family and friends bring a greater impact on their purchase decision making process, than seeing celebrities or influencers.

But the results of current research in 2020 about influencer marketing among practitioners are different (Taylor, 2021). YPulse youth marketing expert in 2020 published a report on influencer marketing. This research is documenting young consumers, and for them influencers are "as influential as ever" (YPulse, 2020). The report shows compared to previous year $54 \%$ it increased to a $70 \%$ margin; the data shown that $13-18$-year-olds are more likely to follow 
online influencers. And not only that the data shows $58 \%$ of Gen $\mathrm{Z}$ and $48 \%$ of millennials made purchased base on an influencer's recommendation. And another interesting point from the report, is says that young consumers are showing interest in how celebrities and influencer handles the COVID19 pandemic and quarantine situation. This market analyzes prove that the influencer marketing method is a new trend and is a great opportunity for companies and brands to reach consumers and get purchases especially from young people.

\section{Conventional Marketing vs Internet Marketing}

When comparing digital marketing methods with conventional traditional marketing practices, it is shown that there are many areas and opportunities showing that digital marketing tends to be more competent and always preferred over conventional methods during a pandemic.

In contrast to traditional marketing where waiting becomes a time-consuming part because there is a defined time frame to know the results of campaign and response from the customer, while at the other hand online marketing results are real time and very dynamic. Internet marketing allows companies and brands to respond to their customers in real time, with everything connected it becomes easier to track whether the campaign creating the result needed or is it creating the right traffic for a specific product or not; it could be seen directly base on consumers feedbacks. And with the flexible and connected setting it allows companies and brands to make an appropriate change in the campaign before the campaign ends, while in the other hand it is not possible to be done in traditional marketing because it is not as flexible as internet marketing.

From opportunity point of view, traditional marketing possible medias for campaign are not suitable for small companies, because they need to compete with bigger companies in the market. The opportunity sometimes become impossible because of the costs involved and the expertise of strategy making for traditional media. While in the case of internet marketing through online media, any business or all types of companies can carry out the marketing process according to the cost each.

Cost is the point that makes the difference between traditional marketing approaches and digital marketing; with the limitless media options, flexible budget, different targeting channels companies or brands can customize their own digital marketing strategies base on their needs. The cost can vary starting from very little until super expensive. It really depends on the spending and it replaces the expensive traditional marketing methods that has a specific publish rate such as advertising in print media, radio, television, and magazine coverage.

Through digital marketing provides a much wider reach. This wide reach without limitations is possible because on the internet there are no regional limitations like conventional marketing. Creating the right content, selecting the right targeting will give all companies the opportunity to go international.

The consumer journey or what is often called the customer journey is more focused in digital marketing. The application of this pattern can be clearly directed, such as from social media to the website and then directed to purchases. It is very different from conventional marketing, where the customer journey pattern cannot be directed directly.

\section{CONCLUSION}

Internet marketing is now way more advance that previous year, and it has grown rapidly. Business is changing their business aspects due to the advances in information technology, now options like digital marketing activities, and also online transaction methods create limitless possibilities and opportunities. Specifically, during this hard time, COVID19 pandemic, many businesses has transformed their business using digital approach that also includes internet marketing. businesses have transformed transactions through digital marketing. The pandemic has accelerated the growth of digital marketing which has made an impact on the change of behavior from consumer towards online transactions. Consumers at this time search more using internet facilities to find information about the best offers from sellers or companies compared to the old method. Cha (2009) also determined in his study that the more people who find shopping services on social networking sites useful and easy to use, the more likely they are to shop for goods on social networks. The wide variety of consumers who utilize social networks means that most of the target market is reachable (Cha, 2009). Shankar et al (2011) also revealed in their study that social media (eg, Twitter, Facebook, and LinkedIn) plays a huge part in purchase intent process, more shippers make the decision based on their social media interaction and information.

In a good way digital marketing has bring a huge commercial impact on businesses, cost is no longer a constrain for them to do marketing because of the wide opportunity available. Now it becomes more equal to all business, not only big companies can enjoy marketing tools, but small companies are now able to create campaign with their given budget, and with that they can still reach the targeted market. And since the market is open with limitless possibilities now small companies can compete with larger companies, on an equal base (Fred \& Paul, 1998). This is a great opportunity for companies of various sizes to develop their business during the pandemic. 


\section{REFERENCES}

[1] Ahlers, D, "Local web search examined," In Dirk Lewandowski (Ed.), Web search engine research (Library and Information Science, Vol. 4, pp. 47-78), 2012.

[2] Ancarani, Fabio and Venkatesh Shankar, "Symbian: Customer Interactions through Collaboration and Competition in a Convergent Industry," Journal of Interactive Marketing, 17 (1), 56-76, 2003.

[3] Arndt, Johan, "Role of Product-Related Conversations in the Diffusion of a New Product," Journal of Marketing Research, 4 (August), 291-95, 1967.

[4] Arnott, Pai. P, "User adoption of social networking sites: Eliciting uses and gratifications through a means-end approach," Computers in Human Behavior, Volume 29, Issue 3, Pages 1039-1053, 2013.

[5] Association of National Advertisers, “Advertisers love influencer marketing: ANA study," https://www.ana.net/ content/show/id/48437, 2018 (Accessed on: 23 April, 2021).

[6] Bampo, Mauro, Michael T. Ewing, Dineli R. Mather, David Stewart, and Mark Wallace, "The Effects of the Social Structure of Digital Networks on Viral Marketing Performance,” Information Systems Research, 19 (3), 273-90, 2008.

[7] Berger, Jonah and Katy Milkman, "Social Transmission, Emotion, and the Virality of Online Content," https:// www.msi.org/wp-content/uploads/2020/06/MSI_Report_10-114.pdf, 2011. (Accessed on: 23 April 2021).

[8] Blažková, M. Jak využít, "Internet v marketingu: krok za krokem k vyšší konkuren-ceschopnosti," Grada Publishing. ISBN 80-247-1095-1, 2006.

[9] Bolton, Ruth N. and Shruti-Saxena Iyer, "Interactive Services: Framework, Synthesis and Research Directions," Journal of Interactive Marketing, 23 (1), 91-104, 2009.

[10] Burghardt, M., Heckner, M., \& Wolff, C, "The many ways of searching the web together: A comparison of social search engines (Vol. 4)," In D. Lewandowski (Ed.), Social information research. Bradford: Emerald Group Publishing Limited, 2012.

[11] Cetină. J, Cristiana. M, Rădulescu. V, "Psychological and Social Factors that Influence Online Consumer Behavior," Procedia - Social and Behavioral Sciences, Vol 62, Page 184-188, 2012.

[12] Cha, Jiyoung, "Shopping on Social Networking Websites: Attitudes towards real versus virtual items," Journal of Interactive Advertising, 10: 77-93, 2009.

[13] Chaffey. D, "Definitions of E-marketing vs Internet vs Digital marketing," Smart Insight Blog, 2013.

[14] Cheng, J. H., \& Liu, S. F, “A study of innovative product marketing strategies for technological SMEs,” Journal of Interdisciplinary Mathematics, 20(1), 319-337, https://doi.org/10.1080/09720502.2016.1258837, 2017.

[15] Choudhury, P., Koo, W. W., \& Li, X, "Working (From Home) During a Crisis: Online Social Contributions by Workers During the Coronavirus Shock Working (From Home) During a Crisis: Online Social Contributions by Workers During the Coronavirus Shock," Working Paper 20-096, 2020.

[16] Colborn, J, "Search marketing strategies: A marketer's guide to objective driven success from search engines," Oxford, UK: Butterworth-Heinemann, 2005.

[17] Damien Geradin \& Dimitrios, “An EU competition law analysis of online display advertising in the programmatic age,” European Competition Journal, 15:1, 55-96, DOI: 10.1080/17441056.2019.1574440, 2019.

[18] De Bruyn, Arnaud and Gary L. Lilien, “A Multi-Stage Model of Word-of-Mouth Influence Through Viral Marketing," International Journal of Research in Marketing, 25 (3), 151-63, 2008.

[19] Deighton, John, and Leora Kornfeld, "Interactivity's unanticipated consequences for markets and marketing," Journal of Interactive Marketing, 23 (1), 4-10, 2009.

[20] Dolan, R., Conduit, J., Fahy, J., \& Goodman, S, "Social media: communication strategies, engagement and future research directions," International Journal of Wine Business Research, 29(1), 2-19. https://doi.org/10.1108/ IJWBR-04-2016-0013, 2017.

[21] Durmaz, Y., \& Efendioglu, I. H, “Travel from Traditional Marketig to Digital Marketing," Global Journal of Management and Business Research: E Marketing, 6(11), 173. https://doi.org/10.23956/ijermt.v6i11.60, 2016.

[22] Dushinski, Kim, “The Mobile Marketing Handbook: a Step-by-step Guide to Creating Dynamic Marketing Campaigns." Paperback on Amazon.com, 2009.

[23] eMarketer, “Advertisers boost social ad budgets in 2013,” Retrieved from https://www.emarketer.com/Webinar/ Digital-Advertising-Trends-2013/4000064, 2013. (Accessed on: 23 April, 2021).

[24] Eric Schwartz, "What Do People Talk About? Drivers of Immediate and Ongoing Word-of-Mouth," Journal of Marketing Research, forthcoming, 2011. 
[25] Farrar, M, "Understanding digital marketing," The British Journal of Administrative Management Vol. 71 (Summer), pp. 12-14, 2010.

[26] Fernandez, A. A., \& Shaw, G. P, "Academic Leadership in a Time of Crisis: The Coronavirus and COVID-19," Journal of Leadership Studies, https://doi.org/10.1002/jls.21684, 2020

[27] Fred Palumbo, Paul Herbig, "International marketing tool: The Internet," Industrial Management \& Data Systems, Vol. 98 Iss: 6, pp.253 - 261. Publisher: MCB UP ltd, 1998.

[28] Galea, S, “Leveraging your content's value,” Journal of Digital Asset Management. Vol. 3 No. 5, pp. $259-262$, 2007.

[29] Gladwell, Malcolm, “The Tipping Point: How Little Things Can Make a Big Difference,” Boston: Back Bay Books, 2002.

[30] He, H., Li, Y., \& Harris, L, "Social identity perspective on brand loyalty,” Journal of business research, 65(5), 648657, 2012.

[31] Helm, Roland. Möller, Michael. Mauroner, Oliver. Conrad, Daniel, "The effects of a lack of social recognition on online communication behavior," Computers in Human Behavior, Vol 29, pg 1065-1077, 2013.

[32] Jackson, N, "Infographic: Using social media to build brand loyalty," Retrieved from https://www.theatlantic.com/ technology/archive/2011/07/infographic-using-social-media-to-build-brand-loyalty/241701/, 2011. (Accessed on: 23 April, 2021)

[33] Jonah Peretti, "Viral Marketing for the Real World," Harvard Business Review, 85 (5), 22-23, 2007.

[34] Kalish, Shlomo, Vijay Mahajan, and Eitan Muller, "Waterfall and Sprinkler New-Product Strategies in Competitive Global Markets," International Journal of Research in Marketing, 12 (2), 105-119, 1995.

[35] Kanttila, Nina Koiso, "Digital Content Marketing: A Literature Synthesis," Journal of Marketing Management, Volume 20, Issue 1-2, pg-45-65, 2004.

[36] Kaplan, A. M., \& Haenlein, M, "Users of the world, unite! The challenges and opportunities of social media," Business Horizons, 53, 59-68, 2010.

[37] Kiani, Reza G, "Marketing opportunities in the digital world”, Internet Research, Vol. 8 No. 2, pp. 185-194. https:// doi.org/10.1108/10662249810211656, 1998.

[38] Kim, R. Y, “The Impact of COVID-19 on Consumers: Preparing for Digital Sales,” IEEE Engineering Management Review, 8581(c), 1-1. https://doi.org/10.1109/emr.2020.2990115, 2020.

[39] Kotler, P., Keller, L, “Marketing management,” Grada Publishing, ISBN 80-247-1359-5, 2007.

[40] Lee, H.S, "Social media and YouTube as an attractive marketing tool," The Journal of American Business Review. Vol. 1 No. 2, pp. 249-255, 2013.

[41] Libai, Barak, Eitan Muller, and Renana Peres, “The Role of Seeding in Multi-Market Entry,” International Journal of Research in Marketing, 22 (4), 375-93, 2005.

[42] Lufkin B, "Coronavirus: The psychology of panic buying," The BBC, https:/www.bbc.com/worklife/ article/20200304-coronavirus-covid-19-update-why-people-are-stockpiling, 2020. (Accessed on: 23April, 2021)

[43] Mangold, W. G., \& Faulds, D. J, "Social media: The new hybrid element of the promotion mix," Business Horizons, 52, 357-365, 2009.

[44] Parsons. AJ, Zeisser. M, Waitman. R, ”Organizing for digital marketing,” McKinsey Quarterly, 1996.

[45] Pepelnjak, J Chandler, “Measuring ROI beyond the last ad,” Atlas Institute, Digital Marketing Insight, 2008.

[46] Phillips, D, “Online public relations,” Grada Publishing. ISBN 80-247-0368-8, 2003.

[47] Porter, Lance and Guy J. Golan, "From Subservient Chickens to Brawny Men: A Comparison of Viral Advertising to Television Advertising," Journal of Interactive Advertising, 6 (2), 30-38, 2006.

[48] Purkayastha, A., \& Sharma, S, "Gaining competitive advantage through the right business model: analysis based on case studies,” Journal of Strategy and Management, 9(2), 138-155, 2016.

[49] Rohm, Crittenden, Hanna, "We're all connected: The power of the social media ecosystem," Business Horizons, Volume 54, Issue 3, Pages 265-273, 2011.

[50] Ryan, D. and Jones, C, "Understanding Digital Marketing: Marketing Strategies for Engaging the Digital Generation," Marketing Industry Network. Glasgow, 2009.

[51] Sen, R, “Optimal search engine marketing strategy,” International Journal of Electronic Commerce, 10(1), 9-25, 2005.

[52] Shankar, Venkatesh, Jeffery Inman, Murali Mantrala, Eileen Kelley, and Ross Rizley, "Innovations in Shopper Marketing: Current Insights and Future Research Issues," Journal of Retailing 1s29-s42, doi:10.1016/j. jretai.2011.04.007, 2011. 
[53] Smith, A.N., Fischer, E. and Yongjian, C, "How does brand-related user-generated content differ across YouTube, Facebook, and Twitter?,” Journal of Interactive Marketing. Vol. 26 No. 2, pp. 102-113, 2012.

[54] Song, YB, "Proof That Online Advertising Works," Atlas Institute, Seattle, WA, Digital Marketing Insight, 2001.

[55] Statista, Hootsuite \& We Are Social, "Digital 2020: Global Digital Overvie," Retrieved from https://datareportal. com/reports/digital-2020-global-digital-overview, 2020 (Accessed on: 23 April 2021)

[56] Statista, Hootsuite \& We Are Social, "Digital 2020: Indonesia,” Retrieved from https://datareportal.com/reports/ digital-2020-indonesia, 2020. (Accessed on: 23 April 2021)

[57] Tan, K. S., Chong, S. C., \& Lin, B, "Intention to use internet marketing: A comparative study between Malaysians and South Koreans.,” Kybernetes, 42(6), 888-905. https://doi.org/10.1108/K-12-2012-0122, 2013.

[58] Taylor, C.R, “Is Covid making marketing influencers more influential?” Forbes, https://www.forbes.com/sites/ charlesrtaylor/2020/07/30/is-covid-making-marketing-influencers-more-influential/, 2020. (Accessed on: 23 April 2021)

[59] Thelwall, M, "Web crawlers and search engines," In Jens-Erik Mai (Ed.), Link analysis: An information science approach. Bradford: Emerald Group Publishing Limited, 2015.

[60] Toubia, Olivier \& Stephen, Andrew \& Freud, Aliza, "Viral Marketing: A Large-Scale Field Experiment. Economics, Management and Financial Markets," 6. 10.2139/ssrn.1469603, 2009.

[61] Trusov, Michael, Randolph E. Bucklin, Koen Pauwels, "Effects of Word-of-Mouth Versus Traditional Marketing: Findings from an Internet Social Networking Site,” Journal of Marketing: Vol. 73, No.5, pp.90-102, 2009.

[62] Van der Lans, Ralf, Gerrit van Bruggen, Jehoshua Eliashberg, and Berend Wierenga, “A Viral Branching Model for Predicting the Spread of Electronic Word-of-Mouth," Marketing Science, 29 (2), 348-65, 2010.

[63] Wade, J, “The new wild west,” Risk Management. Vol. 56 No. 8, pp. 26-31, 2009.

[64] Watts, Duncan J, “The 'New' Science of Networks,” Annual Review of Sociology, 30, 243-70, 2004.

[65] Widianingsih, Yuliani, Cahyani, Intan Putri, "Digital Storytelling Melalui Media Sosial dalam Aktivitas Kehumasan Pada Perguruan Tinggi Alih Status,” CHANNEL: JURNAL KOMUNIKASI, Vol. 8 No. 2, 2020.

[66] YPulse, "3 stats that show influencers are as influential as ever,” YPulse daily. New York: YPulse, 2020

[67] Zhang, Guoying, Alan J. Dubinsky, Yong Tan, "Impact of Blogs on Sales Revenue," International Journal of Virtual Communities and Social Networking, Vol .3, Pg 60-74, 2013.

[68] Zhu, M., Yang, Y., \& Hsee, C. K, “The Mere Urgency Effect,” Journal of Consumer Research, 45, 673-690, https:// doi.org/10.1093/jcr/ucy008, 2018. 